\title{
Matkakirjallisuuden kokemus ja maailma
}

Matkakirjallisuus on perinteikäs ja alati uudistuva kirjallisuuden osa-alue, joka yhdistää omakohtaisuutta ja maailmaa koskevia havaintoja ainutlaatuisella tavalla. Tutkimuksen kannalta matkakirjallisuus on antoisa kohde, jonka kautta voi perehtyä esimerkiksi subjektiivisen tilan ja paikan kokemuksen, identiteetin, vierauden kohtaamisen ja kulttuurisen vuorovaikutuksen kuvaukseen kirjallisuuden keinoin. Läheinen yhteys historiankirjoitukseen, matkustamisen historiaan ja kartografiaan, taidehistoriaan, maantieteeseen sekä etnografiaan on ilmeinen, mutta aihepiiri tarjoaa runsaasti haastavia kysymyksiä myös tietokirjallisuuden, kertomuksen ja omaelämäkerrallisen kirjoittamisen tutkijoille.

Aiemmin matkakirjallisuutta tutkittiin paljolti historiallisena, maantieteellisenä ja antropologisena aineistona, mutta tutkimusalan vakiinnuttua huomio on siirtynyt myös matkakirjallisuuden historiaan, retoriikkaan ja poetiikkaan, muotoihin ja teemoihin. Teoksia ei voi määritellä matkakirjallisuudeksi kuitenkaan vain muodollisiin piirteisiin vedoten. Jo tämän numeron kirjoitusten perusteella matkakirjallisten teosten kirjo näyttäytyy moninaisena. Tosiperäisen matkakirjan ytimessä on matka toimintana, kokemuksena ja käytäntönä. Lajia määrittävät myös kirjalliset traditiot ja lukijan odotukset. Monen matkakirjan taustaoletuksena on esimerkiksi, että aikalaislukija voisi vierailla samoissa paikoissa tai jopa toistaa saman matkan, jos ei todellisuudessa niin mielikuvituksessaan. Menneen maailman matkakirjallisuuden lukija taas voi hahmottaa mielessään todellisia paikkoja sellaisina kuin ne joskus koettiin.

Tällä hetkellä aiheen kansainvälinen tutkimus on vilkasta, monipuolista ja tieteidenvälistä. Aiheeseen liittyvää tutkimusta julkaistaan runsaasti, mukaan lukien sille omistetut tieteelliset journaalit (Studies in Travel Writing, Journeys, Viatica) ja julkaisusarjat (Routledge Research on Travel Writing, Anthem Studies in Travel Writing). Molempien julkaisusarjojen kustantajat ovat hiljattain julkaisseet myös matkakirjallisuuden tutkimuksen suuntauksia laajasti käsittelevät käsikirjat, joita Ilona Lindh esittelee teemanumerossamme. Ranskalainen vuonna 1984 perustettu matkakirjallisuuden tutkimuskeskus, Le Centre de Recherche sur la Littérature des Voyages (CRLV), määrittelee roolinsa vahvasti monitieteiseksi tutkimukseksi kohteensa mukaisesti, ja pyrkii tuomaan yhteen kirjallisuudentutkijoita monelta suunnalta, historioitsijoita, taidehistorioitsijoita sekä maantieteen ja kansatieteiden tutkijoita. Keskuksen tehtävä heijastelee hyvin tutkimusalan nykyistä luonnetta: tutkia matkakirjallisuutta sen kaikissa ilmenemismuodoissa, niin dokumentaarisessa, esteettisessä kuin ideologisessa ulottuvuudessa aina yksinkertaisimmista päiväkirjoista ja -muistiinpanoista kaunokirjallisiin matkakirjoihin saakka. CRVL on myös 
julkaissut matkakirjallisuuden tutkimukseen keskittynyttä journaalia Viatica vuodesta 2014. Muualla Euroopassa matkakirjallisuuden tutkimuskeskuksia on esimerkiksi Nottingham Trent -yliopistossa, jossa on toiminut vuodesta 2002 lähtien Centre for Travel Writing Studies (CTWS), ja pohjoissaksalaisen Eutinin kaupungin tutkimuskirjastossa, jossa on vaikuttanut saksankielisen historiallisen matkakulttuurin tutkimuskeskus vuodesta 1992. Tutkimus Nottinghamissa keskittyy moderniin matkakirjallisuuteen 1700-luvulta alkaen ja Eutinissa kerätään, luetteloidaan ja tutkitaan matkakirjallisuutta 1500-luvulta nykypäivään.

Tutkimusalan vakiintuneisuudesta kertovat myös lisääntyvä yliopistollinen opetus, tutkimusverkostot ja -järjestöt sekä säännöllisesti järjestettävät konferenssit. Alalle omistautunut kansainvälinen tutkijajärjestö International Society for Travel Writing perustettiin 1997. Matkakirjallisuuteen ja -kulttuuriin keskittyvää Borders and Crossings -konferenssisarjaa on järjestetty vuodesta 1998 ja siihen on osallistunut monia suomalaisia kirjallisuudentutkijoita. Matkakirjallisuuden tutkimuksen teemat ovat varsin yleisiä myös muissa kirjallisuudentutkimuksellisissa konferensseissa. Leena Eilittä kirjoittaa tässä numerossa Ranskan Lillessä syyskuussa 2019 pidetystä European Society of Comparative Literature -yhdistyksen konferenssista, jossa hän yhdessä Sandra Vlastan kanssa järjesti matkakirjallisuuteen ja identiteettiin keskittyneen työpajan.

Kirjallisuudentutkimuksen ja fiktion teorian kannalta matkakirjallisuuden sijoittuminen kauno- ja tietokirjallisuuden rajamaastoon on haasteellinen kysymys. Matkakirjat ovat vaikuttaneet romaanikirjallisuuteen ja päinvastoin. Rajanvedon ongelman tuovat erityisen hyvin esille teokset, jotka yhdistävät tosiperäiseen matkaan fiktiivisiä aineksia tai kertovat matkasta kaunokirjallisin keinoin. Tätä huokoista vuorovaikutuksen osa-aluetta tarkastelee Kai Mikkonen esseessään "Kysymyksiä fiktion ja tosiperäisen matkakertomuksen suhteesta ranskalaisessa 1800-luvun matkakirjallisuudessa". Faktan ja fiktion lomittuminen oli tyypillistä myös 1600-luvun japanilaisessa kikōbunmatkakirjallisuudessa, jota Niklas Salmi käsittelee artikkelissaan "Tyhjyyden metaforat Matsuo Bashōn matkakertomuksessa Kapea tie pohjoiseen". Bashōn matkakertomus (noin vuodelta 1694) on haibun-muotoinen eli se yhdistelee proosamuotoista matkakerrontaa ja haikuja. Niklas Salmi keskittyy artikkelissaan siihen, kuinka matkakirjallisuuden kuvaamia mentaalisia tiloja voidaan analysoida kognitiivisen metaforateorian avulla.

Lajin kysymykset nousevat esiin kolmessa nykysuomalaista kirjallisuutta käsittelevässä artikkelissa. Sarianna Kankkusen artikkelissa "Komedia Vantaanjoella: peripateettinen laji, tilallisuus ja komedia ympäristövastuullista lähimatkakirjallisuutta rakentamassa" analyysin kohteena on Maarit Verrosen Pieni kumikanoottikirja (2011), jossa voi nähdä piirteitä esseen, matkakertomuksen, peripateettisen kirjallisuuden ja komedian lajeista. Kankkunen tarkastelee erityisesti sitä, miten lajipiirteet ja tilallisuus rakentavat teoksen ympäristövastuullisuutta. Mikko T. Virtanen puolestaan tutkii yleistajuisiin tietokirjoihin upotettuja matkakertomuksia artikkelissaan "Asemointi ja tutkijakuvat 
tiedettä popularisoivien biologien matkakertomuksissa". Virtanen lähestyy tekstejä tietokirjallisuuden tutkimuksen viitekehyksessä ja tarkastelee, miten tutkijan identiteetti muotoutuu matkakerronnan avulla. Ralf Kaurasen tutkimuskohteena on sarjakuvan muodossa kerrottu matkakertomus artikkelissa "Multimodaalinen monikielisyys Katja Tukiaisen matkasarjakuvassa Postia Intiasta". Tukiaisen dokumentaarisessa ja omaelämäkerrallisessa Postia Intiassa -sarjakuvassa (2002) matkan aikaisiin kohtaamisiin liittyy keskeisesti kielten moninaisuus, joka sarjakuvassa saa sekä kuvallisen että sanallisen muodon.

Tässä numerossa käsitellään monen kielialueen, aikakauden ja matkakirjallisuuden muodon edustajia. Yhdistäviä tekijöitä kirjoituksissa ovat tutkittavan kirjallisuuden tosiperäisyys sekä kiinnostus matkan ja kirjoittamisen yhteyteen, matkustajan ja muiden ihmisten ja vieraan kulttuurin vuorovaikutukseen, paikan kuvaukseen sekä omakohtaisen kokemuksen esittämiseen.

Ilona Lindh \& Kai Mikkonen 